\begin{tabular}{|c|c|c|c|}
\hline \multirow{2}{*}{$\begin{array}{r}\text { Case Reports in } \\
\text { Gastroenterology }\end{array}$} & \multicolumn{2}{|c|}{ Case Rep Gastroenterol 2015;9:253-260 } & \multirow[b]{2}{*}{$\begin{array}{l}\text { Karger } \\
\text { Open access }\end{array}$} \\
\hline & $\begin{array}{l}\text { DOI: 10.1159/000437292 } \\
\text { Publisned online: July 2Z, } 2015\end{array}$ & $\begin{array}{l}\text { (C) } 2015 \text { S. Karger AG, Basel } \\
1662-0631 / 15 / 0092-0253 \$ 39.50 / 0 \\
\text { www.karger.com/crg }\end{array}$ & \\
\hline & \multicolumn{2}{|c|}{$\begin{array}{l}\text { This is an Open Access article licensed under the terms of the Creative Commons } \\
\text { Attribution-NonCommercial } 3.0 \text { Unported license (CC BY-NC) (www.karger.com/OA } \\
\text { license), applicable to the online version of the article only. Distribution permitted for non } \\
\text { commercial purposes only. }\end{array}$} & \\
\hline
\end{tabular}

\title{
Presentation, Diagnosis, and Management of Esophageal Lichen Planus: A Series of Six Cases
}

\author{
Diana L. Franco ${ }^{a}$ Sameer R. Islam ${ }^{b}$ Dora M. Lam-Himlin ${ }^{c}$ \\ David E. Fleischer ${ }^{b}$ Shabana F. Pasha ${ }^{b}$ \\ ${ }^{a}$ Department of Internal Medicine, ${ }^{b}$ Division of Gastroenterology, and ${ }^{c}$ Department of \\ Pathology and Laboratory Medicine, Mayo Clinic, Scottsdale, Ariz., USA
}

\section{Key Words}

Esophageal lichen planus · Idiopathic disorder · Squamous cell carcinoma

\begin{abstract}
Lichen planus (LP) is an idiopathic disorder that presents with cutaneous and genital manifestations. Esophageal LP (ELP) was first described by Al-Shihabi and Jackson [J Laryngol Otol 1982:96:567-571] in 1982. Only approximately 80 cases have been documented in the literature since. It is a rare and underrecognized disorder, leading to a delay in diagnosis and a lack of standardized management. We describe the presentation, diagnosis, and management of 6 cases of ELP, at a tertiary institution, because we believe that an increasing awareness of this condition can help identify more cases and increase our understanding of this interesting condition.

(C) 2015 S. Karger AG, Basel
\end{abstract}

\section{Introduction}

Lichen planus (LP) is an idiopathic disorder characterized by cutaneous and genital manifestations. Esophageal LP (ELP) is a rare and underrecognized disorder, with a delayed diagnosis and a lack of standardized management. To our knowledge, since the first case report in 1982, only 80 cases of ELP have been described. The diagnosis is suspected by esophageal endoscopic findings, including white papules, pinpoint erosions, and esophageal pseudomembranes, and confirmed by the presence of typical Civatte bodies on histopathology and fibrin deposition on direct immunofluorescence. It can be associated with squamous cell carcinoma (SCC) of the esophagus, but no causative relation has been confirmed. Pa-

KARGER 125/s $\quad \begin{aligned} & \text { Diana L. Franco } \\ & \text { Department of Internal Medicine, Mayo Clinic } \\ & 13400 \text { East Shea Blvd } \\ & \text { Scottsdale, AZ } 85259 \text { (USA) } \\ & \text { E-Mail franco.diana@mayo.edu }\end{aligned}$


Franco et al.: Presentation, Diagnosis, and Management of Esophageal Lichen Planus: A Series of Six Cases

tients respond to management with endoscopic dilation and topical steroids but often require subsequent treatment. We describe the clinical presentation, diagnosis, and management of 6 cases of ELP at a tertiary institution. An improved awareness and understanding of ELP may allow for a timely diagnosis and improved management of this disorder. The fact that it is associated with SCC should move physicians to take greater precautions to rule out ELP, especially in patients with dysphagia and mucocutaneous LP lesions.

\section{Case 1}

A 75-year-old male was referred for an evaluation of dysphagia and recurrent food impactions. Five years prior to his presentation, he had undergone endoscopic balloon dilations of proximal and distal esophageal strictures. He was on omeprazole $20 \mathrm{mg}$ daily. Esophagogastroduodenoscopy (EGD) at our institution was significant for a proximal esophageal stricture $20 \mathrm{~cm}$ from the incisors. Sequential balloon dilation was performed using 8to 14-Fr wire-guided American Bard dilators. Esophageal biopsies revealed squamous epithelium with numerous intraepithelial lymphocytes. The patient was initiated on topical fluticasone $220 \mu \mathrm{g}$ twice daily for 8 weeks. His symptoms resolved with this management, but recurred after 10 months. The patient required 2 additional dilations over 3 years for recurrent strictures in the proximal esophagus. No esophageal malignancy, skin, or oral mucosal involvement was diagnosed over a 3-year follow-up period.

\section{Case 2}

A 69-year-old female presented with a 1-year history of intermittent dysphagia to solid foods. EGD showed a proximal esophageal stricture with a 'pseudomembranous' appearance (fig. 1). Endoscopic dilation was performed with 9- to 12-Fr wire-guided American Bard dilators. Esophageal biopsies were not obtained. The patient received a course of nystatin for presumed candida esophagitis. She subsequently developed oral and vulvar lesions, with urethral and vaginal stenosis. The biopsies showed ulcerated squamous epithelium with intraepithelial lymphocytes, consistent with mucocutaneous LP. Over the following 2 years, the patient required 3 additional esophageal dilations for recurrent dysphagia. The esophageal biopsies were consistent with ELP. The patient was treated with a course of oral steroids (prednisone $20 \mathrm{mg}$ daily for 2 weeks). She remained asymptomatic for about 10 months and subsequently required 4 additional dilations over a 7-year follow-up period. No malignancy was diagnosed during that time.

\section{Case 3}

A 67-year-old female with a past medical history significant of mucocutaneous LP diagnosed 2 years prior presented for an evaluation of dysphagia and intermittent 'choking spells'. She was on prednisone $5 \mathrm{mg} /$ day, omeprazole $20 \mathrm{mg} /$ day, and topical triamcinolone $(0.1 \%$ twice a day). She had undergone an esophageal dilation approximately 1 year ago. EGD at our institution revealed inflammation and a stricture in the proximal esophagus. Biopsies revealed diffuse, acute chronic inflammation and focal individual cell keratinization with lymphocytes, consistent with LP. Intralesional injection of triamcinolone and dilation was performed. The patient remained asymptomatic for a period of 2 years, but subsequent- 
Franco et al.: Presentation, Diagnosis, and Management of Esophageal Lichen Planus: A Series of Six Cases

ly required 5 additional dilations and a steroid injection into the proximal esophageal stricture of $20 \mathrm{ml}$ triamcinolone $(10 \mathrm{mg} / \mathrm{ml})$. She did not receive medical therapy. She was diagnosed with a squamous papilloma of the midesophagus 11 years after the initial diagnosis of ELP, but did not develop esophageal malignancy.

\section{Case 4}

A 20-year-old female with recurrent oral ulcers was referred by an ENT specialist for an evaluation of dysphagia and odynophagia. A biopsy of the oral ulcers revealed mild spongiosis, with lichenoid lymphocytic infiltrate and plasma cells. The esophagus appeared endoscopically normal, and midesophageal biopsies showed squamous mucosa with lymphocytic infiltration and a lichenoid chronic inflammatory infiltrate within the lamina propria. The patient was initiated on topical fluticasone at $220 \mu \mathrm{g}$ twice daily for 8 weeks but was lost to follow-up.

\section{Case 5}

A 76-year-old female with mucosal LP presented to our clinic with a 4-year history of solid food dysphagia and self-limited episodes of food impaction. Two months prior, EGD at another institution had revealed a midesophageal stricture that was dilated. Biopsies were consistent with severe acute esophagitis. EGD at our institution was significant for mid- and distal esophageal strictures that were dilated with a $13.5-\mathrm{mm}$ balloon dilator. Biopsies revealed a dense lymphocytic infiltrate in the lamina propria extending to the atrophic squamous epithelium with a few dyskeratotic cells. The patient's symptoms resolved after dilation. She was initiated on topical fluticasone at $220 \mu \mathrm{g}$ twice daily. No malignancy was diagnosed at 1 year of follow-up.

\section{Case 6}

A 61-year-old female with a history of recurrent esophageal candidiasis and LP of the skin was referred to our institution for an evaluation of dysphagia and odynophagia. An EGD with dilation had been performed at an outside institution, without improvement in symptoms. The patient was initiated on omeprazole $20 \mathrm{mg}$ daily and on budesonide $3 \mathrm{mg}$ daily, with symptomatic improvement. EGD at our institution showed a ringed esophagus and white exudates throughout the esophagus, but no strictures. The mucosa was noted to be easily sloughed with the endoscope. Biopsies from the proximal and distal esophagus revealed a dense lymphoid infiltrate in the lamina propria. Brushings of the esophagus revealed candida. Triamcinolone $20 \mathrm{ml}(10 \mathrm{mg} / \mathrm{ml})$ was injected into the middle third of the esophagus. The patient received a course of oral fluconazole $200 \mathrm{mg}$ daily for 21 days and was continued on budesonide $3 \mathrm{mg}$ twice a day and then on $3 \mathrm{mg} /$ day for $10 \mathrm{months}$. The patient remained asymptomatic at 1 year of follow-up. 
Franco et al.: Presentation, Diagnosis, and Management of Esophageal Lichen Planus: A Series of Six Cases

\section{Discussion}

LP is an idiopathic inflammatory disorder of the skin and its appendages and mucous membranes [1]. LP constitutes $0.1-1.2 \%$ of all skin disorders [2]. ELP is a rare disorder and, to our knowledge, approximately 80 cases have been described since the first report in 1982 [3]. Diagnosis is important because of the tendency of ELP to cause persistent dysphagia resulting from esophagitis and stricture formation [4]. The disorder predominantly involves females, with only 8 reported cases being males [5]. We diagnosed 6 patients with ELP at our institution from 1992 to 2013. The female-to-male ratio was 5:1, with a median age of 69 years (range 20-76). The clinical, endoscopic findings and disease management are summarized in table 1.

Dermatologists should maintain a low threshold for requesting a gastroenterology consultation in patients with mucocutaneous LP and esophageal symptoms. Esophageal symptoms may precede, occur in conjunction with, or develop after the diagnosis of mucocutaneous LP [6]. Four of our patients (67\%) had cutaneous manifestations (skin and oral mucosa) prior to presenting with ELP. In our case series, dysphagia was the predominant symptom (83\%), followed by odynophagia (50\%) and food impaction (33\%). The mean duration of symptoms prior to diagnosis was 2.6 years (range 1-5). ELP may be misdiagnosed as reflux esophagitis or candida esophagitis, which may lead to a delay in diagnosis. Three patients $(50 \%)$ in our case series had received a proton pump inhibitor for reflux symptoms. One of the patients had candida esophagitis, but this was in the setting of oral budesonide treatment.

EGD plays a diagnostic and therapeutic role in these patients. Endoscopic findings include white papules, pinpoint erosions, esophageal pseudomembranes, and inflamed mucosa. The findings may be mistaken for reflux esophagitis, eosinophilic esophagitis, or candida esophagitis [7, 8]. ELP may be distinguished from reflux esophagitis endoscopically by the sparing of the gastroesophageal junction. Biopsies are necessary to differentiate ELP from other disorders. Strictures in ELP occur more commonly in the proximal esophagus [6]. Some authors have proposed a progression from inflammation through ulceration, fibrosis, and stricture formation, correlating the longer duration of disease presentation with strictures. The endoscopic findings in our patients included proximal esophageal strictures (50\%), distal esophageal strictures (17\%), ringed esophagus (17\%), white exudates $(17 \%)$, and normal esophagus (17\%). The patient with a normal appearing esophagus had the shortest duration of symptoms (1 year).

ELP histopathology includes a dense band-like lymphocytic infiltrate in the lamina propria, basal layer degeneration, and Civatte bodies, which are characterized by necrotic keratinocytes (fig. 2) [8-10]. Direct immunofluorescence reveals fibrinogen deposition along the dermoepithelial interface. ELP may be associated with esophageal SCC. There are 4 reported cases of ELP progressing to esophageal SCC in the literature [6]. One of the patients in our series developed esophageal squamous papilloma after 5 years of esophageal symptoms, but none of the patients developed esophageal malignancy.

Systemic corticosteroids are considered the first-line treatment of ELP. Topical fluticasone propionate has recently been used, with mixed results [7]. It has the advantage of rapid action, and minimal absorption and side effects of systemic steroids. In our series, 2 patients were treated with topical fluticasone. They achieved symptomatic relief for a limited time.

Topical tacrolimus and oral cyclosporine have been traditionally used for genital LP, and recent case reports have shown success with oral forms of these medications [11]. 
Franco et al.: Presentation, Diagnosis, and Management of Esophageal Lichen Planus: A Series of Six Cases

In patients who remain symptomatic despite medical management, endoscopic dilation is a viable option. The earlier concerns of stricture induction by the Koebner phenomenon (lesions along the lines of trauma) resulting from endoscopy or dilation have not been supported in the literature. However, there is no evidence showing aggravation of the esophageal strictures [2]. Endoscopic dilation with bougie dilators was performed in 5 patients (83\%; mean $10 \mathrm{Fr}$, range 5-15) in our series. All patients reported improvement in dysphagia but developed recurrent symptoms, requiring repeat dilations. There were no adverse events with dilation.

\section{Conclusions}

ELP is an underrecognized disorder that may be mistaken for reflux or candida esophagitis. The diagnosis is confirmed by the presence of typical Civatte bodies on histopathology and fibrin deposition on direct immunofluorescence. Treatment options are topical steroids and endoscopic dilation. Patients with mucocutaneous LP and upper gastrointestinal symptoms should undergo an evaluation for esophageal involvement due to the high incidence of symptomatic strictures and the reported association with SCC.

\section{References}

1 Boyd AS, Neldner KH: Lichen planus. J Am Acad Dermatol 1991;25:593-619.

2 Ukleja A, DeVault KR, Stark ME, Achem SR: Lichen planus involving the esophagus. Dig Dis Sci 2001;46:2292-2297.

3 Al-Shihabi BM, Jackson JM: Dysphagia due to pharyngeal and oesophageal lichen planus. J Laryngol Otol 1982;96:567-571.

4 Abraham SC, Ravich WJ, Anhalt GJ, Yardley JH, Wu TT: Esophageal lichen planus: case report and review of the literature. Am J Surg Pathol 2000;24:1678-1682.

5 Nielsen JA, Law RM, Fiman KH, Roberts CA: Esophageal lichen planus: a case report and review of the literature. World J Gastroenterol 2013;19:2278-2281.

6 Fox LP, Lightdale CJ, Grossman ME: Lichen planus of the esophagus: what dermatologists need to know. J Am Acad Dermatol 2011;65:175-183.

7 Donnellan F, Swan MP, May GR, Kandel G, Marcon NE, Kortan PP: Fluticasone propionate for treatment of esophageal lichen planus. A case series. Dis Esophagus 2011;24:211-214.

$\checkmark 8$ Chryssostalis A, Gaudric M, Terris B, Coriat R, Prat F, Chaussade S: Esophageal lichen planus: a series of eight cases including a patient with esophageal verrucous carcinoma. A case series. Endoscopy 2008;40:764-768.

-9 van der Meij EH, Reibel J, Slootweg PJ, van der Wal JE, de Jong WF, van der Waal I: Interobserver and intraobserver variability in the histologic assessment of oral lichen planus. J Oral Pathol Med 1999;28:274277.

10 Chandan VS, Murray JA, Abraham SC: Esophageal lichen planus. Arch Pathol Lab Med 2008;132:1026-1029.

11 Chaklader M, Morris-Larkin C, Gulliver W, McGrath J: Cyclosporine in the management of esophageal lichen planus. Can J Gastroenterol 2009;23:686-688. 
Franco et al.: Presentation, Diagnosis, and Management of Esophageal Lichen Planus: A Series of Six Cases

Table 1. Patient characteristics

\begin{tabular}{|c|c|c|c|c|c|c|c|c|c|}
\hline $\begin{array}{l}\text { Age, } \\
\text { years }\end{array}$ & Sex & $\begin{array}{l}\text { Skin/oral } \\
\text { involvement }\end{array}$ & Symptoms & $\begin{array}{l}\text { PPI } \\
\text { therapy }\end{array}$ & $\begin{array}{l}\text { Endoscopic } \\
\text { findings }\end{array}$ & $\begin{array}{l}\text { Dila- } \\
\text { tions }\end{array}$ & $\begin{array}{l}\text { Intra- } \\
\text { lesional } \\
\text { steroids }\end{array}$ & $\begin{array}{l}\text { Medical } \\
\text { treatment } \\
\text { (fluticasone) }\end{array}$ & $\begin{array}{l}\text { Esophageal } \\
\text { malignancy }\end{array}$ \\
\hline 75 & male & unknown & $\begin{array}{l}\text { dysphagia, } \\
\text { food impaction }\end{array}$ & yes & $\begin{array}{l}\text { proximal } \\
\text { stricture }\end{array}$ & 6 & no & no & no \\
\hline 71 & female & yes & dysphagia & & proximal stricture & & & & no \\
\hline 67 & female & yes & $\begin{array}{l}\text { dysphagia, } \\
\text { odynophagia, } \\
\text { oral ulcers }\end{array}$ & yes & $\begin{array}{l}\text { proximal stricture } \\
\text { and esophagitis }\end{array}$ & 12 & yes & no & $\begin{array}{l}\text { no } \\
\text { (squamous } \\
\text { papilloma) }\end{array}$ \\
\hline 20 & female & yes & $\begin{array}{l}\text { dysphagia, food } \\
\text { impaction }\end{array}$ & no & normal & 0 & no & yes & no \\
\hline 76 & female & yes & $\begin{array}{l}\text { dysphagia, } \\
\text { odynophagia }\end{array}$ & no & $\begin{array}{l}\text { middle and lower } \\
\text { third stricture }\end{array}$ & 1 & no & yes & no \\
\hline 61 & female & unknown & odynophagia & yes & $\begin{array}{l}\text { ringed esophagus, } \\
\text { white exudates }\end{array}$ & 0 & yes & yes & no \\
\hline
\end{tabular}

PPI = Proton pump inhibitor . 
Case Reports in
Gastroenterology

Case Rep Gastroenterol 2015;9:253-260

DOI: 10.1159/000437292

(C) 2015 S. Karger AG, Basel

www.karger.com/crg

Franco et al:: Presentation, Diagnosis, and Management of Esophageal Lichen Planus: A Series of Six Cases

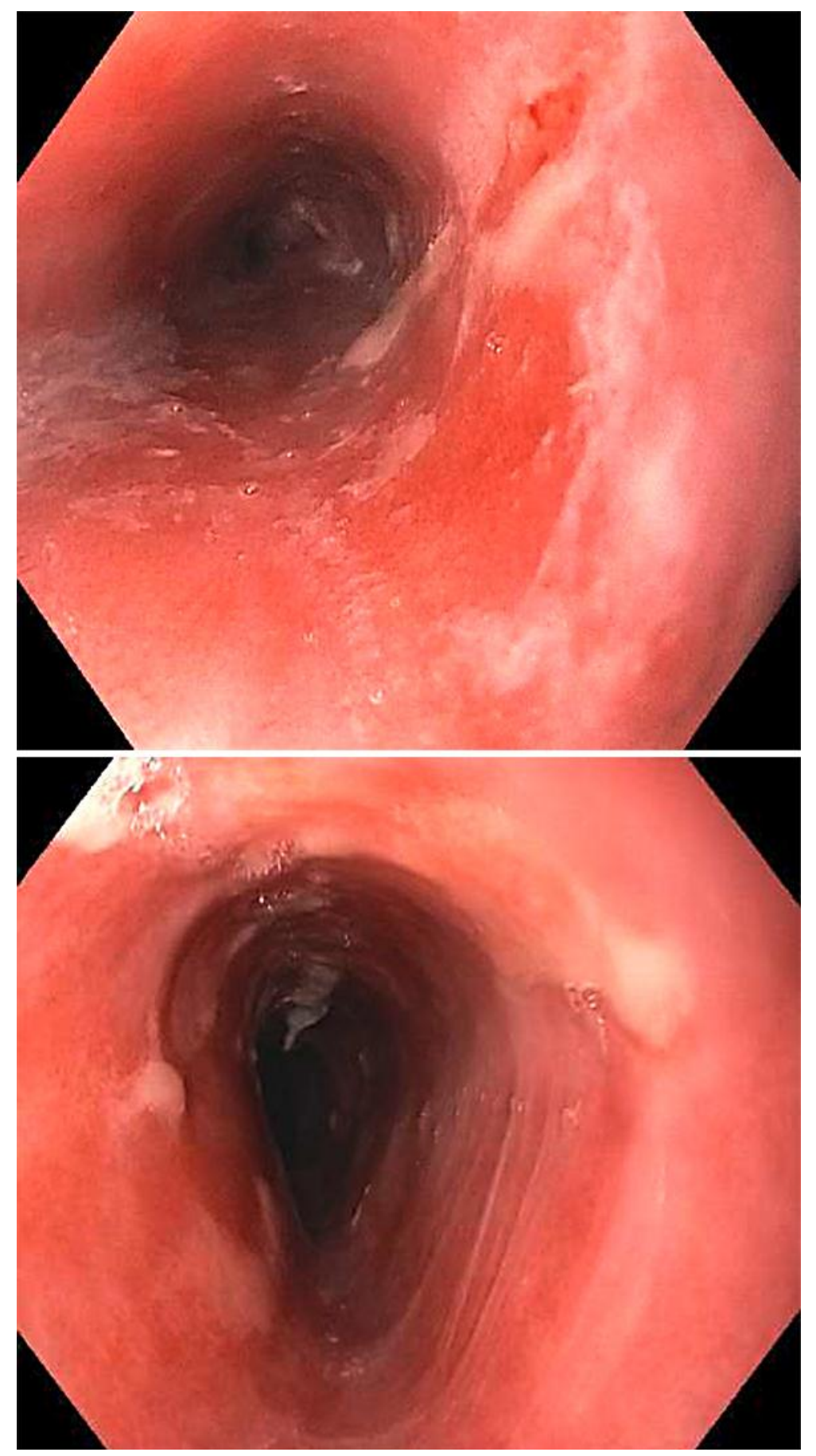

Fig. 1. Endoscopic findings of LP: esophageal pseudomembranes and fibrosis. 


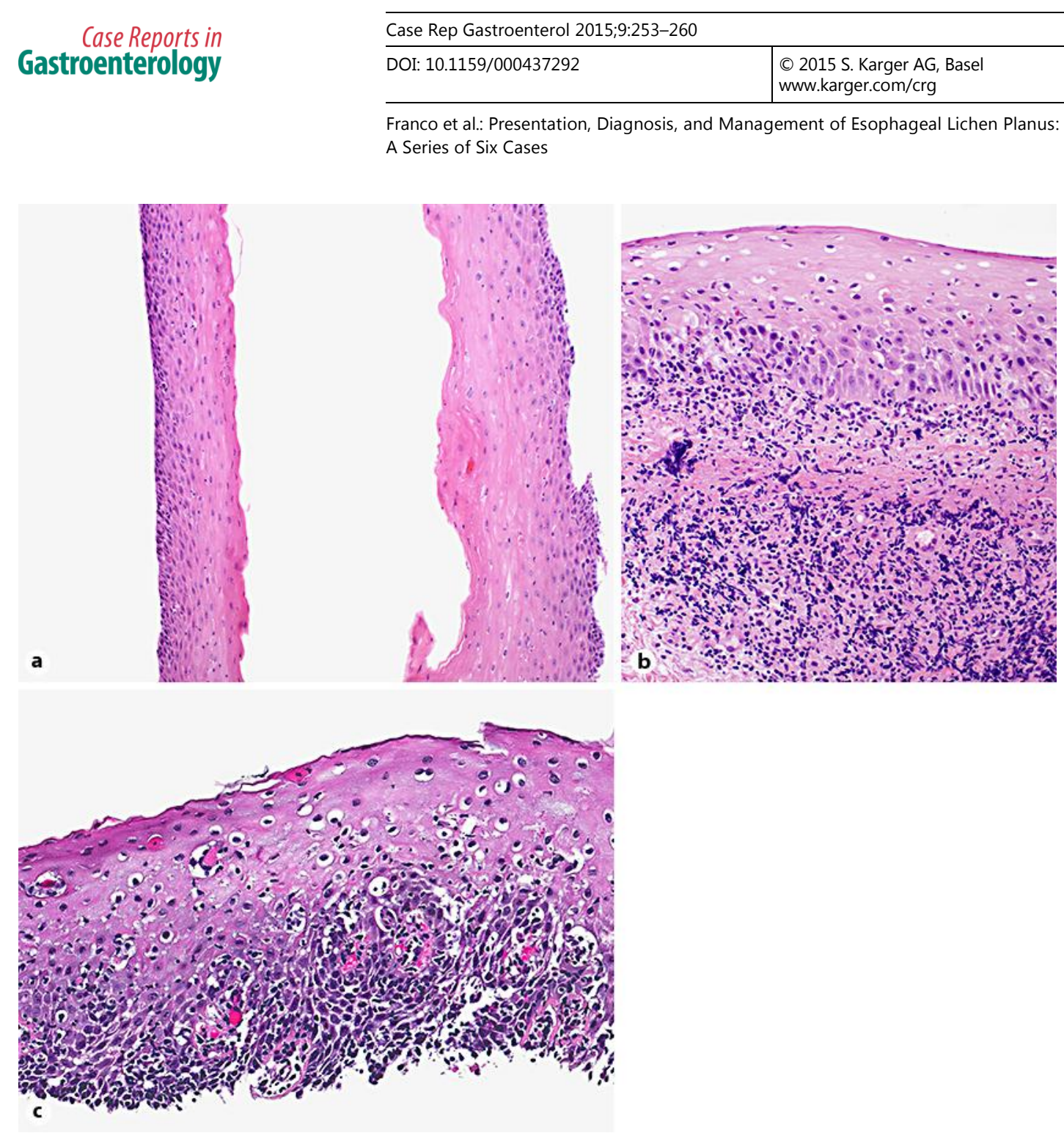

Fig. 2. Histopathologic findings of LP. a Squamous epithelium in the middle and distal esophagus. H\&E. $\times 40$. b Variable thickness of the epithelium. H\&E. $\times 10 . c$ The arrows point to the Civatte bodies. H\&E. $\times 60$. 